\title{
Conflicts for Land and Territory: An Analysis of Internal Migration in the Rural Areas of Colombia
}

\author{
Flor Edilma Osorio Pérez
}

\begin{abstract}
This article compiles some elements of analysis on the problems of displacement of the rural population in Colombia. To that end, we gathered quantitative and testimonial data and articulated perspectives at national ${ }^{1}$ and local ${ }^{2}$ levels. Four aspects are discussed: conflicts for land and territory, some characteristics of the displaced population, the uncertainty of the alternatives and the government presence and role.

\section{Précis}

Cet article procède à la compilation d'un certain nombre d'éléments d'analyse concernant le problème du déplacement des populations rurales en Colombie. Dans ce but spécifique, nous avons réuni des données quantitatives et des témoignages en articulant les perspective aux niveaux national et local. Quatre aspects sont discutés: les conflits terriens et territoriaux, un certain nombre de caractéristiques des populations déplacées, le caractère incertain des alternatives, le rôle et la présence du gouvernement.

\section{Dynamics of the Conflict for Land and Territory}

Forced displacement in Colombia is a historical phenomenon, together with armed conflicts, which are half resolved and renewed years later with the increased force of retaliation. Many of these conflicts, situated within the dynamics of the "dirty war," appear to

Flor Edilma Osorio Pérez is Professor-researcher at the Institute of Rural Studies-Master's Program in Rural Development, Pontificia Universidad Javeriana, Santafé de Bogotá, Colombia. Osorio Perez is also a consultant for Human Rights and Displacement and is also a member of the NGO CODHES.

This article was translated from Spanish by Monica Riutort and Associates. be linked to the fight for political power.

In the first half of this century the fight was between the two political parties, Liberal and Conservative; later on, from the beginning of the 1960s, with the intervention of the guerrillas of various affiliations; and from the beginning of the 1980s, with the rise of drug trafficking, new armed players, such as hired assassins, paramilitary and self-defense groups, enter the scene. Alliances are built according to interest, and even when they have national links, they develop regional strategies. All of these have carried on with impunity from the authorities who are unable to provide equitable solutions to the conflicts.

In addition to political power, the armed conflicts have implicated economic interests of regional and local players. One of the immediate consequences of war is the evacuation of space by a frightened rural population who sell their land at ridiculous prices or abandon it in the face of imminent threat of death. In this way, the internal war has articulated two conflicts not yet resolved: territory and land. The territorial conflict has to do with the control and ownership of strategic spaces. Political and economic interests converge in this conflict, which requires the subordination of the resident population by terror. The conflict for land is more limited because it focuses only on productive physical space. The land still constitutes a prestige factor, power and an investment, which maintains and strengthens the structure of wealth in the country.

Although these two conflicts could happen independently, they have easily superimposed themselves on one another. In May, 1996, about 700 families left the rural zone of Batata in the direction of Tierralta. ${ }^{3} \mathrm{~A}$ displaced women from the rural zone of Tierralta municipality gave the following explanation:

The guerrillas gave the order. The paramilitary were sacrificing many people. People were letting themselves be killed. People were disappearing. The guerrillas were also killing. This was a change. They were burning buses. It turned into a confrontation. And then, from one moment to the next came the order that everyone must vacate the land, within a given period of time. The guerilleros did not want to leave the land, nor did the paramilitary. In situations like this, the one in the middle is the peasant. The land thus vacated became a battleground for the paramilitary and the guerillas.

However, in addition to the land, there are major infrastructures, such as highways, the port and a potential interoceanic channel tht are part of the hidden interests that explain the violence in the Uraba Region.

The interest of the displaced in land is manifested in several ways. In the case of Tierralta, as one peasant explained, "They said to us that they are going to buy INCORA, the peasants need to give a power of attorney." When intermediaries made these offers, they paid 600,000 to 700,000 (Colombian) pesos per hectare, not the best price, but still possible.

After checking on these procedures, and informing the farmers that this might be a trick, the strategy changed. Armed men came to let them know that they were buying at 40,000 to 50,000 pesos per hectare. "But, if you do not sell, we will buy easily from the widow," was a common threat, according to a testimony of a local peasant.

The registry of 395 families consulted originates from 13 blocks in the municipality, and accounts for about 12,000 hectares of fertile land, owned in many instances without formal 
ownership titles. Only 20 percent of families have returned and there are several blocks that are still empty.

\section{The Urban Displaced: Some Characteristics}

Every month in 1995, in Colombia about one thousand homes with rural ties were forced to leave their homes and their work. This means that every three out of four families with rural ${ }^{4}$ ties were displaced. The same study registered that eight of every ten HVR displaced had access to land, but only six of the ten were owners of land. Their parcels of land belong to micro and small parcels 5 that were for the most part abandoned. In a country in which 75 percent of the population is rural, two out of three displaced people had a rural tie, which exemplifies the impact of this phenomenon on the rural population.

For the Tierralta sample, all of the displaced depended for their livelihood on agriculture and cattle-raising, which means that many were motivated to return to renew their agricultural activities with some seed and belongings. Gradually, close to 500 families returned to Batata, some only partially, because they stayed in the village rather than their farms because of fear. In Batata, where there is a National Military base, the returnees formed a Cooperative, CONVIVIR, ${ }^{6}$ around which some paramilitary groups have been formed. These groups have been intimidating the population, assassinating peasants with list in hand, stealing, threatening and raping women. A displaced peasant of Tierralta described the situation succinctly:

These youngsters came with the displaced population. Here they did everything they could, but they couldn't work. Then, they went up to see if they could get work in the harvest. There what did they have to harvest? There, what they were able to achieve was entrance to the cooperative CONVIVIR to pick on people at night, and to kill them.

This situation makes the possibility of returning remote. Thus, approxi- mately 200 families stayed in Tierralta and this number continues to increase because those who had returned are displaced again and again as well by people from other municipalities in Uraba. According to a displaced peasant,

this is an emergency, because people are suffering. They are adapting to this way of life, but they are not settled and truly when you do not have a place to stay, you are destroyed. The people who work in the country, those who plant the seeds so we all can eat should be welcome, looked on with respect, appreciated in the village or the town. Today, on the contrary they are the most deprived.

Displacement produces serious problems in the home life of each family member, independently of age and gender. According to a national study, six of every ten children of HVR displaced are below 15 years of age and eight of every ten children are of school age, but they can not attend primary school. As well, one quarter of the HVR displaced have a woman as head of the family. For these women the only economic alternative is the informal economy in the cities.

One of the characteristics of rural violence is the selectivity of the armed players against the leadership of the local society. They are the leaders of the peasant organizations. This intimidates and displaces the families. One of every ten HVR heads interviewed at the national level acknowledge belonging to a social organization before their departure. The selective strategy dissuades the organizing process in rural civil society which, after displacement, has very little resources to organize itself to denounce the situation as a flagrant violation of human rights, as they face certain poverty. The traumatic experiences further diminish their political participation.

The search for resources to survive in the city confronts the HVR displaced immediately since they are not trained to work in jobs beyond agriculture and cattle raising. For every ten heads of HVR households, two have not had any formal education and six have fin- ished only primary school or attended partial primary school. One of the ten has finished high school or attended high school without graduating and only one has technical or higher education.

"In the country a person does not need to know how to read and write, but in the city you do," said a displaced peasant in Tierralta.

In the National Survey, of ten HVR displaced, four heads of families had not received any earnings in the past month, three had received the equivalent of half the minimum ${ }^{7}$ salary, two had received up to half or full minimum salary, and only one received more than a minimum salary.

The above conditions mark the daily life of approximately one million persons, who have left their land in the past eleven years. However, this does not really represent the magnitude of the problem. The geographical extent of the problem involves departures from more than 600 municipalities and relocation to 100 municipalities, in addition to the large cities. What has happened in the first quarter of 1997 shows a significant increase in this phenomenon, particularly the mass exodus of entire populations from one part of the country to others or outside the country. ${ }^{8}$

The National Study registers as the cause of displacement, first, paramilitary groups $(26 \%)$, second, guerrillas $(21 \%)$. However usually people indicated several armed players, without indicating clearly who they were. Usually the strategy of the armed groups is to identify themselves as belong to a different group so as to confuse the people. A consensus among the displaced is that fear is a major factor in abandoning their land.

\section{The Uncertainty of the Alternatives}

While 36 percent of displaced peasants in the country, wanted to return to their land between 1985 and 1994, in 1995 , only 18 percent of HVR heads of household wanted to do so. In fact, 60 percent preferred to stay in the new place of residence. Relocation to another place was the preferred option 
for 18 percent of those registered in the National Survey.

Displacement seriously weakens the rural tie, because only one of every three homes which had access to land before will consider returning to it now, or considered that the land could provide any source of income for the family. The National Survey calculated that between 70 and 80 percent of the displaced population from the countryside has totally and definitively lost its rural ties. Other economic alternatives such as micro-industry and wage labour were a possibility among 30 to 33 percent of the displaced population. Any decision, however, will depend on real opportunities that can be offered to them to solve some of the most urgent needs, such as jobs that will allow them to recover its own selfesteem.

The alternatives are few and slow to come. In Tierralta, for example, the Municipal administration were concerned that if they provided solutions in the city many more displaced people would come. As one displaced women acknowledged:

The situation is very difficult, it is critical. There are a large number of people here, with so many problems, unemployment, housing, children without school, or if the children are admitted, they are expelled shortly after because they do not have uniforms, they are not well dressed or they do not have the school supplies.

The roots of the problem are the abuse perpetrated by the armed groups, legal and illegal, the impunity with which they do so, and the lack of protection of the civil population. "The solution is not easy, because the strength of money is one thing, Money here is power. I think for those who have money, money is God. I think the best way to succeed and to have peace is to dialogue," said a displaced peasant woman in Tierralta.

\section{The Government Presence}

The institutional presence of the government has been slow, ineffectual, insufficient and ambiguous. In spite of a historical presence and a recent increase in the dimensions of the problem in Colombian society, the government did not even recognize the displacement situation until 1995. This was possible for several reasons: on one hand, a permanent pressure by NGOs, who were the first to register and attend to the problem; second, the Organization of Displaced Persons, which emerged to claim their rights and to denounce the continued and outrageous violations.

Recognition was also possible because of a number of studies which published information on the situation. Particularly important was the study done by the Colombian Episcopate, ${ }^{10}$ which reported on many national and international incidents, because it came out of an institution with enough credibility. Finally, the weight of reality and the resonance given in the media made this country's drama visible.

In 1995, the government of Ernesto Samper promulgated the document CONPES No. $2804,{ }^{11}$ in which the government proposed some criteria and defined institutional responsibilities to deal with the situation. The Office of Displaced Persons was opened as part of the Human Rights Unit, which is a division of the Ministry of the Interior. The Ministry of the Interior was called before the Ministry of Government.

In 1997, in the face of international pressure, particularly from Europe, the First Lady was given the mandate to work on this problem. In April, the Presidential Council for Displaced was formed. All this institutional movement in a short period of time has been mediated by a propagandistic approach. In practice, this Office is still not fully competent when it comes to evaluating effectiveness, resources are insufficient, and interventions are often opportunistic and inappropriate. Furthermore, its power to sanction is very limited. The work of the Office takes place in an institutional culture that it is inefficient and corrupt. Often, there isn't any knowledge or commitment to resolving such a delicate problem, where the displaced are easily confused with voluntary migrants.
This year there was another CONPES, No. 2994, and in July, Law No. 387 was approved which

adopts measures for the prevention of forced displacement, socioeconomic strategies, protection, consolidation and stabilization of people internally displaced by violence in the Republic of Colombia.

This is a measure which offers opportunities to the displaced population to demand its rights, but there are no regulations to facilitate its implementation. The law requires the presence of the military and police in all local, regional and national situations to take decisions and pay attention to problems. However, due to the irregularities perpetrated by troops and police and their alliance with the paratroops, this decision is a serious obstacle to the Displaced Services Committees being able to offer enough security guarantees to the population. In the meanwhile, the displacement increases by leaps and bounds.

\section{Conclusion}

Other conflicts and crises in Colombia often hide the impact of displacement, even though manifested in thenational order. The impact is greatest at local and regional areas, which is not always well reflected in the national percentages. We make some final remarks from both perspectives.

Displacement is emerging as a major economic crisis in the agricultural and cattle-raising sector since it diminishes food security in the country. This is more noticeable in the household and at the local level, with an increase in prices and the scarcity of basic foods. As well, it is generating great food and economic dependency for the displaced, which has a high cost at the economic, cultural and political levels. These costs have not been calculated.

Displacement also leads to a geographical reordering that has reached critical proportions at the local level. The displacement leads to a new rural order, with different players that control the territory by violent means, in a process which concentrates land in a 
few hands. The personal history of many Colombians is marked by fear, pain, uprootedness and injustice, which repeats cyclically in the family history.

Simultaneously with the rural displacement, urban slums are established, where at the same time that new solidarity networks are built, other relationships are marked by rejection and competition for scarce resources. It seems that there is no place for families, because the violence continues to grow. Furthermore, intolerance and selfishness among the less poor against new arrivals, contaminates with the violence and poverty and result in intolerable situations. People said: if they are persecuted it is "because they have done something wrong."

In the big cities, even though it is easy to hide the arrival of the newcomers running away from violence, the effects of displacement are cumulative and, exacerbated by unemployment delinquency and misery, become more and more difficult to manage. In a process of decentralized adjustments with serious ambiguities and neocentral tendencies, and in an environment of violence and private justice, there isn't a forum to a debate on civil participation because "to survive, you have to be silenced." The local development of small and medium size municipalities is already fragile in their socioeconomic and political dynamics, and they are further threatened and without protection. How, then to develop local and rural development in a constant stage of war?

The government response is schizophrenic. On one hand, it wants to be seen as a defender of human rights, given international pressure, and, on the other hand, it makes and reinforces statements that increase violation of those rights. The potential and the will to generate a process of capacity-building and a dialogue with armed players, is treated as a joke, in a government with its own governability, legitimacy and credibility crisis.

On the other hand, services for displaced show the waste and the high cost of war. No budget of governmen- tal or non-governmental organization has the capacity to respond effectively to the immediate demand for services, let alone to take specific actions for a comprehensive social recovery of this population. The country cannot consolidate socioeconomic structures for the displaced, and the demand for services continues to increase. As the situation continues and increases, the situation of the displaced continues and is aggravated, so that there seems to be no end to the problems.

As the situation evolves, there is a need to develop intervention strategies that analyze how the local realities of the displaced form the regional and national dynamics of territorial conquest. To back the right of the population and to create dialogue spaces for negotiation there is a need to regenerate a framework for strong support and political willingness from national and international sectors and civil society as a whole. The displaced population continues to reinvent survival strategies and trust that the life will offer a better future, displaying an amazing resistance capacity.

\section{Notes}

1. Data are taken from a study done with Fabio Lozano, of the Presidential Council in Human Rights, as well as from the System of Information for Displaced People, SISDES, CODHES, through the National Surveys for Displaced Population, July, 1994 and October, 1995. The 1996 data from SISDES have not yet been processed, given the many difficulties in public order.

2. This information has been collected as part of the work done by a team of professionals from the Javeriana University with the displaced population of Tierralta. The author is part of this team. The above mentioned consultation was a contract with the Colombian Institute for Agrarian Reform (INCORA). The quotations in brackets are the testimonies of displaced individuals.

3. This Municipality has approximately 70,000 inhabitants, 60 percent from rural areas. It is located in the South-Occident part of the department of Cordoba, in the North of the Country. It is part of the Uraba region with which it has maintained a strong sociocultural and economic alliance.
4. Homes with rural ties, HVR, were considered those who, before displacement, had at least one of these three characteristics: residence in the block, access to land and employment, at least one of the household members works in agriculture and/or cattle raising as either producer or labourer.

5. The definition of micro and minifundios was established according to the Agricultural Family Unit, UAF, according to the agro-ecological conditions of each $\mathrm{mu}$ nicipality.

6. The security groups legally established to support the army with control, information and intelligence. These groups have given rise to an intense debate because of the evidence of serious violations of human rights, with sadistic and cruel strategies to impose control. No limits exist to these cooperatives, to the self-defense units or the paratroops.

7. For this year the minimum salary was 120,000 (Colombian) pesos, or approximately $\$ 120$ U.S.

8. At the beginning of this year, many families crossed the frontier and settled in Panama. They were deported back to Colombia, which is a violation of International Human Rights principles.

9. This movement first emerged from leftist political groups, like the Patriotic Union, which has been one of the most affected, with more than 2,000 dead in six years. The elimination of the "enemy" was extended to all people and groups which were perceived as a threat to the traditional powers, and included civil organizations, unions, teachers, journalists, judges, health promoters, Catholic religion teachers, etc.

10. The study looked at displacement from 1985 and 1994.

11. Document issued by the National Political Social Council.

\section{Bibliography}

Conferencia Episcopal de Colombia. 1995. Desplazados por la Violencia en Colombia (Displaced because of Violence in Colombia). Santafé de Bogotá, D.C.: Editado por la Conferencia Episcopal Colombiana.

Consulta Permanente Sobre Desplazamiento Interno en Las Americas. 1993. "Mision in Situ de asistencia técnica sobre desplazamiento interno en Colombia" (In Situ Technical Assistance Mission about internal displacements in Colombia). Documento policopiado.

Deas, Malcom y Fernando Gaitán Daza. 1995. "Dos Ensayos Especulativos sobre la Violencia en Colombia" (Two Speculative Essays about Violence in Colombia). 
Santafé de Bogoté D.C.: Departamento Nacional de Planeación.

Departamento Nacional de Planeacion. 1995. "Programa Nacional de Atención Integral a la Población Desplazada por la Violencia" (Comprehensive National Services to those Displaced because of Violence). Documento CONPES 2804. Version Aprobada. Santafe de BogotA, D.C.: Documento policopiado.

Osorio Flor Edilma y Fabio Alberto Lozano. 1996. "Poblacion rural en situacion de desplazamiento: Condiciones y Perspectivas" (Rural population facing displacement: Conditions and perspectives). Documento final, presentado a la Consejeria Presidencial para los Derechos Humanos, CODHES, Santafé de Bogotá.

Osorio Perez, Flor Edilma. 1993. La Violencia del Silencio. Desplazados del Campo a la Ciudad (The Violence of Silence: Displaced from the Country to the City). Consultoria para los Derechos Humanos y el Desplazamiento, CODHES y Pontificia Universidad Javeriana. Santafe de Bogotá, D.C. ARFO Ltda.

Presidencia de la Republica, Consejeria Presidencial Para la Atencion Integral a la Poblacion Desplazada or Violencia. Julio de 1997. Los desplazados, Esa Colombia que no podemos ignorar (The displaced, the Colombia we cannot ignore). Santafé de Bogotá, D.C.: Imprenta Nacional de Colombia.

Rojas, Jorge. 1996. "Sistema de Información de Hogares Desplazados por la violencia, SISDES I" (Information Systems of Displaced Households Due to Violence: SISDES I). Informe final presentado a la Consejeria Presidencial para los Derechos Humanos. Consultoria para los Derechos Humanos y el Desplazamiento, CODHES. $\square$

\section{So That Russia be 6s Sayed"? Anti-Jewish Violence in Russia: Its Roots and Consequences}

\author{
By Tanya Basok and Alexander Benifand \\ Toronto: York Lanes Press, 1993 \\ ISBN 1-55014-010-8; 8.5x11 61p; Can. $\$ 9.95$
}

The growing populartity of ultra-nationalismand neo-Nhatisn in Europe and to some extent in North America is truly alarning, and Awis publication offers aperceptive analy sis ot the poltical trends in Russiamd their implications for Russian Jews. It provides an historical analygis of an W Jewish violence in Russia and poses min importent question: can, hose-condilfons which resulted in ant t- Jewish pogroms at the turn of the century reemerge today?

Dr. Basok and Dr. Bentiand argute in this deccasional paper that there is a number of cleat indications of the popularity of the and-Semitic and ultrat nationalist ideas notonly among the masses and rationalist onganibations but in the governmerti as well:

Many of those who have been impoverithed as a result of the "shoek therapy or who have grovin extremely disilwisioned with Yeltsin's reform policies; have become attracted to the solutions such as. getting zid of ethmic minorities, espediny Tews, tertitorial expansion of ho Russhar federation to include the fommer Soviet republics, the extension of the Rassian sphere of

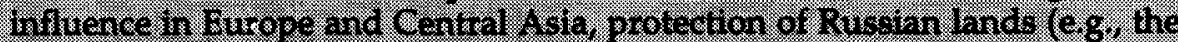
Rurile lslands) and the curbing of ethric nationalism within the Rissian federation. Basol and Bentiand's invightrul analysis is an excellent attempt to wnderstand the tise of utratrationalism in Russia:

$$
\text { 4volitable from: }
$$

\section{Centre for Refugee Studies \\ Fax: (416) 736-5837 \\ Enali:refuge@yorku.ca}

\title{
Breaking Ground:
}

\section{The 1956 Hungarian Immigration to Canada}

\author{
Edited by Robert H. Keysenlingk \\ Toronto: York Lanes Press, 1993, ISBN 1-55014-232-1,117 pages, $\$ 6.99$
}

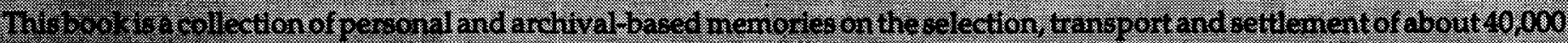

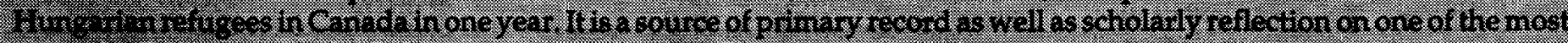

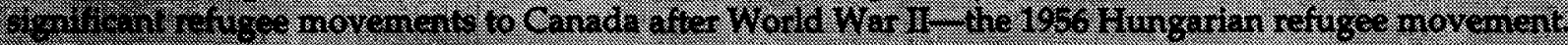

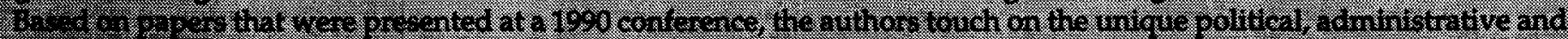

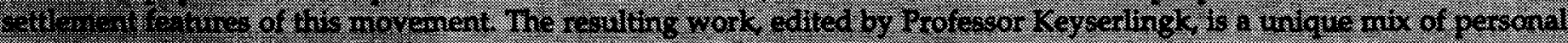

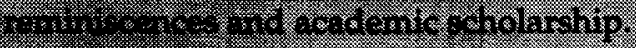

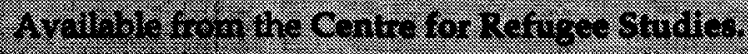

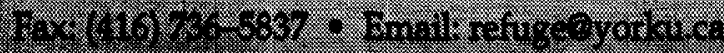

